\title{
Rescue of indigenous knowledge in the practice of Integrated Fire Management, TIs Xerente e Funil, Tocantínia, Tocantins, Brasil
}

\author{
Pedro Paulo Gomes da Silva Xerente ${ }^{1 *}$ e Rejane Carneiro Salvador de Oliveira ${ }^{2 * *}$
}

\author{
${ }^{1}$ Associação dos Brigadistas Xerente, Tocantínia, Tocantins, Brasil \\ 2Instituto Pedagógico de Desenvolvimento Agro-social e Comunitário (INPAC), Itaetê, Bahia, Brasil \\ E-mail for contact: *pedropauloxerente@gmail.com**rejanecarneiro2000@yahoo.com.br
}

\begin{abstract}
The Xerente Indigenous Communities, resident in the Xerente and Funil Indigenous Lands (TIs), located in the Cerrado biome, city of Tocantínia, Tocantins, Brazil, contribute to the Federal Brigades Program from Instituto Brasileiro do Meio Ambiente e dos Recursos Naturais Renováveis (IBAMA) and implemented by the National Center for Forest Fire Prevention and Fighting (PREVFOGO), which has as one of its main objectives to implement Integrated Fire Management in Indigenous Lands, both in preventing and fighting forest fires. The Program began in 2013 and the Xerente people with their knowledge and experience had a great influence on changing forest fire prevention strategies, since these fire were indeed severe and degraded their fauna and flora. The Indigenous people collaborated with the Xerente Indigenous Federal Brigade, which operates in the two aforementioned TIs. At the beginning of the Program's execution, there were some disagreements with the traditional knowledge, because during the Brigade Formation course, promoted by PREVFOGO/IBAMA, the Brigadistas were instructed not to let it burn, and that, all detected fire should be extinguished. Thus, there were a conflict between indigenous culture and the strategy adopted by the Brigade, as the Elders (older indigenous) did not accept this strategy and began to advise the Brigadists about the importance of using fire in the post-rain season, when vegetation is still damp, preventing the managed fire from becoming a forest fire and knowing where it would naturally go out. Meetings between PREVFOGO/IBAMA servants and Elders occurred and there they described the way their ancestors managed fire. The servants valued these popular wisdom and it was build a historical landmark of trust, participation, knowledge exchange and zeal for use of fire. Strategies to prevent major fires were jointly developed. Thus, there was a rescue of the use of fire by the Xerente People, through prescribed burns following the recommendations of the Elders, based on the themes: clearing fire for hunting, cleaning around the villages and farms, ensuring fruiting and escape route to animals. In this sense, every year there has been a reduction of major fires in the Xerente and Funil ITs.
\end{abstract}

Keywords: Brigade, Indigenous Land (TI), Integrated Fire Management, Indigenous and Traditional Knowledge. 